\title{
Combined Laparoscopic-Endoscopic Techniques for Removal of Small Gastric Tumors: Advantages and Tricks
}

\section{Dear Editor,}

We read with great interest the article entitled "Endoscopic full-thickness resection combined with laparoscopic surgery" published by Kim. ${ }^{1}$ This article discussed the minimally invasive techniques for the removal of small gastric tumors that do not require wide gastric resection.

Up to now, minimally invasive techniques for the removal of small gastric tumors include endoscopic and combined laparoscopic-endoscopic resections. Furthermore, the combined laparoscopic-endoscopic resection can be categorized as "cut first and then suture" and "suture first and then cut".

We agree with the author that removing the lesion from the inside of the gastric cavity is advantageous for the treatment of stromal and/or small tumors, which allows for a direct endoscopic visualization of the tumor during resection and avoids excessive gastric tissue resection in addition to all of the advantages for minimally invasive approaches. ${ }^{2,3}$

Some authors, including us, have previously performed a combined laparoscopic-endoscopic removal of gastric tumors. ${ }^{2,4-6}$ In our case, the tumor was an iuxta-cardial gastrointestinal stromal tumor. In the technique that we described previously, ${ }^{4}$ two 5 -mm radially expandable trocars were inserted into the gastric cavity through the abdomen and then the gastric walls. An endoscopic polypectomy snare was introduced through the mouth, which was used to grasp and gain traction on the gastric iuxta-cardial lesion, allowing for good exposure of the excision site. The iuxta-cardial lesion was excised with its full thickness by laparoscopy and placed in a small plastic bag. After the specimen was retrieved through the mouth by means of the endoscopic snare, the gastric holes were laparoscopically sutured.
However, we would like to draw attention to some very important features that were not discussed by Kim. ${ }^{1}$

First, either endoscopic or combined laparoscopic-endoscopic resection of gastric tumors enables the surgeon to resect tumors situated at the gastric location that are difficult to reach by open or laparoscopic surgery.

Secondly, the author did not describe whether the specimen was pulled away from the mouth via the endoscopic snare during the laparoscopic and endoscopic cooperative surgery, as we did in our described technique, ${ }^{6}$ or through an abdominal wall incision by laparoscopy after it was placed in a plastic bag.

Thirdly, it is possible to spare the vagus nerve branches at the outer gastric wall by the minimally invasive techniques cited above, since sparing the tissue around the tumor is easier and safe to perform, and gastric stasis may therefore be avoided.

\section{Conflicts of Interest}

The authors have no financial conflicts of interest.

\section{Author Contributions}

Conceptualization: Eva Intagliata

Data curation: EI

Investigation: EI

Methodology: EI

Resources: EI

Supervision: EI

Validation: Rosario Vecchio

Writing-review\&editing: RV

Eva Intagliata and Rosario Vecchio

Department of General Surgery and Medical Surgical Specialties, University of Catania, Catania, Italy

Received: May 19, 2019 Accepted: May 24, 2019

Correspondence: Eva Intagliata

Department of General Surgery and Medical Surgical Specialties, University of Catania, Policlinico Vittorio Emanuele Hospital, Via S. Sofia 78, 95123 Catania, Italy

Tel: +39-347-067-4195, Fax: +39-095-378-2492, E-mail: evaintagliata@vodafone.it

ORCID: https://orcid.org/0000-0002-8667-457X

(c) This is an Open Access article distributed under the terms of the Creative Commons Attribution Non-Commercial License (http://creativecommons.org/licenses/bync/3.0) which permits unrestricted non-commercial use, distribution, and reproduction in any medium, provided the original work is properly cited. 


\section{REFERENCES}

1. Kim CG. Endoscopic full-thickness resection combined with laparoscopic surgery. Clin Endosc 2018;51:33-36.

2. Barajas-Gamboa JS, Acosta G, Savides TJ, et al. Laparo-endoscopic transgastric resection of gastric submucosal tumors. Surg Endosc 2015;29:2149-2157.

3. Vecchio R, Marchese S, Gelardi V, et al. Laparoscopic splenectomy in patients under the age of eighteen. Experience in 18 cases. G Chir 2011;32:279-285
4. Vecchio R, Marchese S, Amore FF, et al. Laparoscopic-endoscopic rendez-vous resection of iuxta-cardial gastric GIST. G Chir 2013;34:145148.

5. Mino JS, Guerron AD, Monteiro R, et al. Long-term outcomes of combined endoscopic/laparoscopic intragastric enucleation of presumed gastric stromal tumors. Surg Endosc 2016;30:1747-1753.

6. Vecchio R, Marchese S, Spataro L, Ferla F, Intagliata E. Combined laparoscopic and endoscopic excision of a gastric gist. Surg Endosc 2013;27:3501-3502. 